\title{
The Influence of Changing Climate Extremes on the Ecological Niche of Pedunculate Oak in Croatia
}

\author{
Damir Ugarković ${ }^{1 *}$, Ivica Tikvić ${ }^{1}$, Stjepan Mikac ${ }^{1}$, Igor Stankić ${ }^{2}$ Danijela Balta ${ }^{3}$
}

(1) University of Zagreb, Faculty of Forestry, Department of Forest Ecology and Silviculture, Svetošimunska 25, HR-10000 Zagreb, Croatia; (2) Energy and Environmental Protection Institute (EKONERG), Koranska 5, HR-10000 Zagreb, Croatia; (3) Croatian Forest Research Institute, Cvjetno naselje 41, HR-10450 Jastrebarsko, Croatia

* Correspondence: e-mail: damir.ugarkovic@gs.htnet.hr
Citation: UGARKOVIĆ D, TIKVIĆ I, MIKAC S, STANKIĆ I, BALTA D 2016 The Influence of Changing Climate Extremes on the Ecological Niche of Pedunculate Oak in Croatia. South-east Eur for 7 (2): 143-148. DOI: https://doi.org/10.15177/seefor.16-17

Received: 27 Oct 2016; Revised: 28 Nov 2016; Accepted: 30 Nov 2016; Published online: 5 Dec 2016

\begin{abstract}
Background and Purpose: Forest trees are adapted to the specific climatic conditions and other ecological factors that dominate within their distribution range. However, the climate is in constant flux. In addition to natural climatic oscillations, the climate has also been changed directly or indirectly by human activities. The issue of climate change is tied mostly to air temperature and precipitation. The objective of this study was to assess the potential influence of climate change on a part of the ecological niche of pedunculate oak (Quercus robur L.) in Croatia.

Materials and Methods: A forecast model was developed for the ecological niche of pedunculate oak in Croatia from the present day to 2080 using logistical regression, on the basis of a climate change model.

Results: Within the lowland areas of Croatia, the model forecasts an increase in the minimum temperatures of the coldest month and maximum temperature of the warmest month, and reduced precipitation in both the driest and wettest months. Conclusion: The results indicate that climate change will negatively impact the ecological niche of pedunculate oak in the future.
\end{abstract}

Keywords: climate change, ecological niche, pedunculate oak

\section{INTRODUCTION}

The climate is a complex and direct ecological factor that is described using various climatic elements, appearances and indices. Flora is dependent on both weather and climatic conditions. The forest tree species of lowland Croatia are adapted to the specific climatic conditions and other ecological factors that dominate in those areas. However, those climatic conditions change over time, which is reflected on the growth and development of all types of organisms. In recent years, climate changes have been documented worldwide. Hasselmann [1] indicated that the average air temperature has increased $0.5^{\circ} \mathrm{C}$ over the past century. Reduced precipitation has been confirmed in Russia [2], Turkey [3], South Africa [4] and in China [5]. However, no changes in precipitation extremes were recorded at 19 meteorological stations in northern and central Europe [6]. The minimum temperatures increased virtually everywhere, and the maximum and mean temperatures increased in northern and central Europe, Russia and Canada [7]. In
Croatia, Seletković et al. [8] analysed weather data over the past century from the Zagreb - Grič station, indicating that changes to the temperature and precipitation regime have already begun in Croatia.

According to the Fifth National Report of the Republic of Croatia, in line with the United Nations Framework Convention on Climate Change [9], a tendency towards increasing temperatures was found throughout the whole of Croatia. This positive trend has become strongly pronounced over the past 50 years, and particularly in the past 25 years. The increasing mean annual air temperature in the past 50 or 25 years was statistically significant at all weather stations. The total annual precipitation was found to be declining throughout Croatia, during the entire 20th century.

An ecological niche is the position of a species in the ecosystem, in the place where it survives (its habitat) and the way it lives. Every species has specific living conditions and poses various demands towards the habitat it lives in. 
If the ecological niche is examined from the perspective of a population in a certain geographic area, then the climatic and geomorphological factors are of critical importance for the spatial distribution and size of the species range. In addition to air temperature, which is dependent on cloud cover and insolation, water is the most important factor for the development of vegetation, as it presents the main source of moisture in the soil that is required for physiological processes. When the relationship of air temperature and precipitation is considered, it is necessary to take into account that the extreme amounts (minimum and maximum values) of these two ecological factors are the limiting factors for the survival of certain species. Pedunculate oak (Quercus robur L.) requires a large quantity of water for transpiration, which most often can exceeds the quantity of precipitation falling in the vegetation period. For that purpose, pedunculate oak must have access to additional water, such as ground water [10]. The annual transpiration of a 108-year old stand of pedunculate oak is 1,030,000 litres per hectare [11].

With changes to the climate elements, the appearance of the vegetation cover of an area also changes. With the activity of climatic elements, certain species are able to move into new areas or to higher elevations, while their place is taken by other species suited by the altered ecological conditions. Understanding the ecological niche is of key importance for getting better insight on how forest ecosystems functioning. Understanding the interaction of climate and vegetation is one of the most important segments in studying geographic distribution and the success of species. Therefore, the objective of this study was to establish the potential changes in the ecological niche based on a global climate change model to the year 2080 .

\section{MATERIALS AND METHODS}

Pedunculate oak is the most valuable tree species in Croatia, accounting for $27 \%$ of the wood mass in Croatian forests [12].The rotation for pedunculate oak is 140 years [13]. Croatia currently has 201,739 ha of pedunculate oak forests, with a growing stock of 41.5 million $\mathrm{m}^{3}$ [14]. Natural pedunculate oak sites in Croatia are located in the valleys of large rivers and their tributaries, such as the Sava, Drava, Kupa, Danube and others. The most common soil type in these forests is gleyic soil with its subtypes [15]. According to the Köppen classification, there are two climate types within the pedunculate oak forest distribution area in Croatia. The Cfwb" $x$ " type, the temperate rain zone climate, prevails in the west part of the Pannonian Plain. The eastern area between the Sava and Drava rivers is the domain of the Cfwb " $x$ " type climate. This is also a temperate rainy climate, but with only one pronounced precipitation maximum. The mean annual air temperatures range between 10.0 and $11.5^{\circ} \mathrm{C}$. Rainfall ranges from a maximum of about $900 \mathrm{~mm}$ occurs in the western part to less than $600 \mathrm{~mm}$, in the eastern part. The precipitation is relatively evenly distributed throughout the year [16].

The CCM3 (Climate Change Model) model, which represents a concentration of greenhouse gases in the atmosphere twice that of the present day [17], was used to develop the climate change forecast to 2080 . To build the forecast model, the extreme values of climatic elements were used as follows: maximum temperature in the warmest month of the year, the minimum temperature in the coldest month of the year, precipitation in the wettest month in the year and precipitation in the driest month of the year.

Data on the presence of pedunculate oak in the Republic of Croatia were taken from the most recent research on the distribution of forest habitats [18], and the Flora Croatica Database [19]. Modelling the ecological niche was performed in the program MAXENT [20]. Climatic data used to model the ecological niche were taken from the WORLDCLIME database for the period 1950 to 2000 [21]. The ecological niche model for the distribution range of pedunculate oak today and in the year 2080, based on the climate change model, was created using logistical regression [22]. The obtained spatial distribution maps of the ecological niche (GRID format) were converted to a TIFF and visualised in ESRI ArcMap 9.2.

\section{RESULTS}

According to the global climate change model, the minimum temperature of the coldest month and the maximum temperature of the warmest month will increase by $2.2^{\circ} \mathrm{C}$ and $6.7^{\circ} \mathrm{C}$, respectively. The precipitation in the driest and wettest months of the year will decrease by 18.5 $\mathrm{mm}$ and $5.8 \mathrm{~mm}$, respectively (Table 1 ).

Figure 1 shows the probability (\%) of the appearance of pedunculate oak in Croatia, with regard to the climatic conditions. Yellow areas are those with a lower probability of their appearance, while green areas indicate areas where pedunculate oak has a higher probability of appearing with regard to climate. The spatial distribution of the ecological niche of pedunculate oak in the period from 1950 to 2010 corresponds to the actual species distribution range (Figure 1).

With regard to the changing climatic elements, changes in the ecological niche to the year 2080 can also be forecast. Based on the model of global climatic changes, the model forecasts less favourable conditions for pedunculate oak in the area of the Spačva Basin and Podravina (yellow), while there will be more favourable condition in central parts of Croatia (Figure 2).

\section{DISCUSSION}

Global climate change, regardless of how it arises, is a current and ongoing occurrence on Earth. With air temperature, which depends on cloud cover and insolation, precipitation is most significant for the development of vegetation, as this is the primary source of moisture in the soil. A lack of precipitation, with the appearance of high air temperatures, weakens plant resistance, as increased transpiration consumes large quantities of water. The regional climate model used for the scenario of climate changes in Croatia was developed by Dickinson et al.[23] and Giorgi [24]. In the scenario of climate change based on the regional climatic model in Croatia, the mean values of the 30 -year 
TABLE 1. Mean climatic element values for ecological niche modelling for the periods 1950-2010 and 2080

\begin{tabular}{lcccc}
\hline \multirow{2}{*}{ Climatic factors } & \multicolumn{2}{c}{ Period } & Difference \\
\cline { 2 - 4 } & $\mathbf{1 9 5 0 - \mathbf { 2 0 1 0 }}$ & $\mathbf{2 0 8 0}$ & +2.2 \\
\hline Min. temp. coldest month $\left({ }^{\circ} \mathrm{C}\right)$ & 3.6 & 5.8 & +6.7 \\
Max. temp. warmest month $\left({ }^{\circ} \mathrm{C}\right)$ & 28.9 & 35.6 & -18.5 \\
Precipitation driest month $(\mathrm{mm})$ & 38.6 & 20.1 & -5.8 \\
Precipitation wettest month $(\mathrm{mm})$ & 137.3 & 131.5 & \\
\hline
\end{tabular}

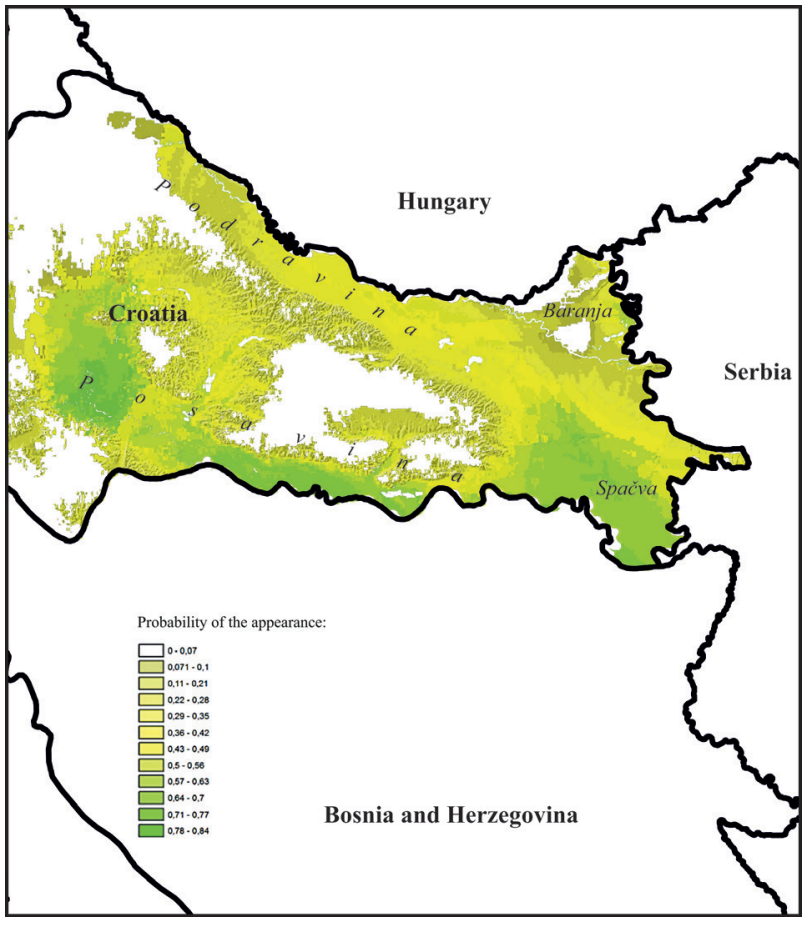

FIGURE 1. Spatial distribution of the ecological niche (potential habitat) of pedunculate oak for the period 1950 to 2010

future climate period (2041-2070) were compared with the 30-year climate average of the reference period (1961-1990). According to that scenario, climate change in all seasons will result in increasing air temperatures, which is statistically significant with a $99 \%$ confidence level. Small changes in precipitation are often accompanied by large increases in the appearance of precipitation extremes $[25,26]$. The regional climate model for Croatia envisaged a reduction in the total quantity of precipitation in three seasons (spring, summer and fall), primarily in the coastal, southern and mountainous parts of Croatia [9]. Climate change can lead to changes in the spatial distribution of forest vegetation that can be seen in the representation of the current forest types, the possible disappearance of existing or appearance of new types, changes in population densities in certain tree types, productivity of forest ecosystems, ecological stability and vitality of forests, and in changes to the total production and general values of forests ecosystem services.
Pedunculate oak is a tree species with a very narrow ecological amplitude in terms of water demand. Over the past century, large changes have a great role in the lowland forest habitats, primarily due to changes in the hydrological conditions. This has affected the reduced stability of the pedunculate forests and of individual tree stability [27].

The effects of climate change can have a negative effect on the ecological niche of one tree species, while other species are positively affected, and the spatial distribution of the ecological niche of those species is increased. Climatic elements, such as the maximum temperature of the warmest month and minimum temperature of the coldest month, and precipitation in the driest and wettest months represent the limiting values of climatic elements that influence the appearance and existence of a species.

The limit values of the presence of a species in most logistical regression models are 0.5 [28]. A higher probability indicates a habitat that is suitable for the appearance of 


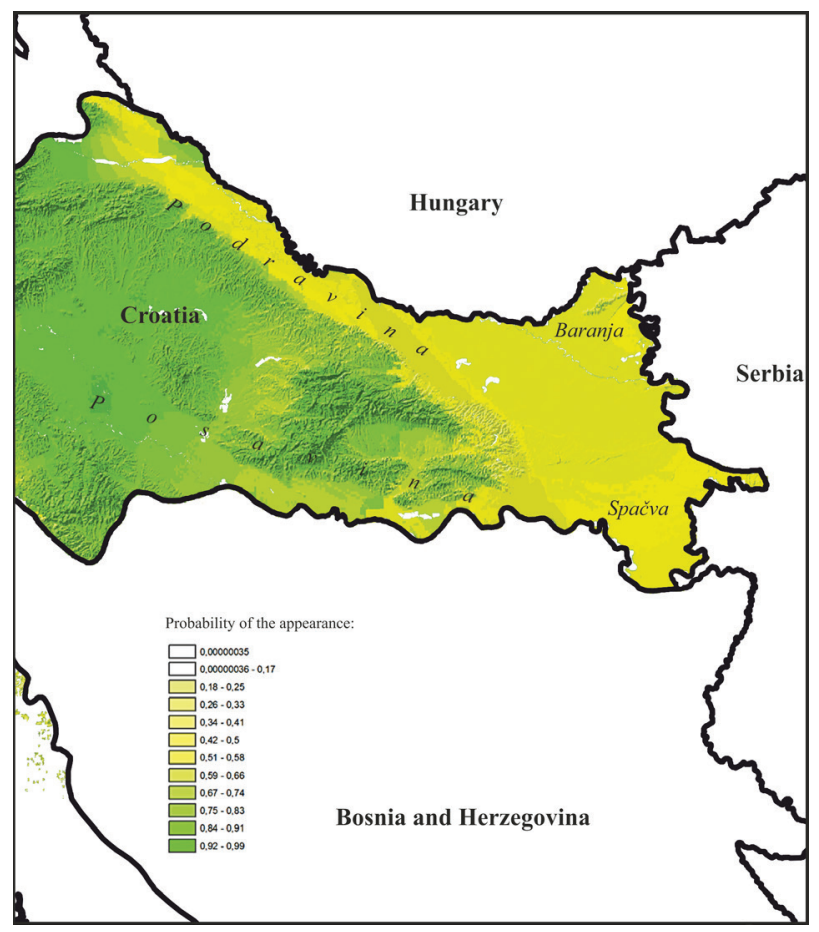

FIGURE 2. Probability of the presence of pedunculate oak to the year 2080 in relation to simulated climatic factors

pedunculate oak with regard to climate elements. Taking into account the changing climatic elements, changes in the ecological niche of pedunculate oak to 2080 can be forecast. According to the forecast model, negative changes to the ecological niche can be expected in the Spačva area (eastern Croatia), while the western part of the Podravina area (northern Croatia) will become unfavourable for the growth of pedunculate oak. The Baranja area will have favourable conditions, while the Posavina area will not see any changes in the ecological niche of pedunculate oak (Figure 2). The natural adaptation of vegetation to climate change occurs on a small percentage of vegetation affected by the climatic elements. A vegetation model indicated that successful adaptation is possible only with very small changes in climate, less then $0.1^{\circ} \mathrm{C}$ per 10 years, and an absolute change in climate of less than $1^{\circ} \mathrm{C}$ [29]. A study on the palaeontological and recent climates in Croatia showed that secular or long-period climate changes, warming or cooling, did not negatively affect the composition of the climazonal vegetation [30]. Those changes only caused a shift in the vegetation belt in the direction from lower elevations towards higher elevations (in the case of warming) and vice versa (in the case of cooling). On the basis of such findings, it can be expected that the future natural climate change or changes caused by the direct or indirect human activities will also cause a shifting of the climazonal vegetation forms, depending on how the climate is changing $[30,31]$.

With regard to the context of the relationship between vegetation and climate, it should be considered that vegetation directly influences and changes the climatic conditions in a certain area through the processes of assimilation and the sequestration of atmospheric $\mathrm{CO}_{2}$ [32]. As such, changes to climate elements result in changes to certain parts of the ecological niche of a species. It is difficult to differentiate and fully elucidate the exclusive activity of climatic elements on the ecological niche of a species, and with that its spatial distribution. An example of this is pedunculate oak, which requires high ground waters and flood waters [27, 33, 34].

The range of temperature and precipitation values for an individual species shows the significance of climatic elements for the appearance of a species. Research on the effect of climatic factors on the ecological niche of a species gives important knowledge on the relationship of the vegetation at the species level towards the environment, particularly towards climate. The current comprehension of the exceptionally large significance of various forms of water (ground water, flood waters and stagnant waters) on the appearance of pedunculate oak should be considered in synergy with climatic elements, particularly temperature.

Forest ecosystems today are very exposed to changes, whether those changes are caused by natural variability or by human activity. Considering the overall synergy of all the ecological factors on the appearance of a specific tree species is one of the fundamental segments in the study and understanding of forest vegetation functioning. Forecast models of climate change should also be taken with a certain reserve, and with consideration of the various possible 
outcomes. Modelling ecological niches and understanding the relationships between vegetation and ecological elements, particularly climate, should be considered at the level of the entire population. However, it is necessary to also consider the possible spatial parts of the population that became adapted to the local climatic conditions over time, and that the ecological niche of these populations varies from that of the remaining part of the population (ecotypes). In that case, future research of the relationships of climate and vegetation should also include studies on genetic variability within populations of the same species.

The climate model used in the present study assumes twice the present level of greenhouse gases in the next hundred years. However, a shortcoming of climate forecast models is that they tend to not consider the influence of vegetation on the global carbon cycle, aerosols, cloud cover and the oceanic-atmospheric links of climate [1]. At the local level, other factors other than climate elements can be of key importance, such as herbivore population density, pathogenic organisms, commercial activities, changes in soil properties, competition, meso- and micro-climatic factors and more.
Models that predict global climate change contain a large amount of entropy, as they do not include all those factors that directly or indirectly affect climate. Future research should continue to model the population densities of pedunculate oak or the ratio of the species at the level of the actual ecological niches in competition with other tree species, including their population growth mechanisms.

\section{CONCLUSIONS}

According to the climate change model, the minimum and maximum air temperatures in the coldest and warmest months will increase, while precipitation of the driest and wettest months of the year will decrease. Climate changes in the future will alter the ecological niche of pedunculate oak, dependent on other ecological factors. Future research should continue to analyse and spatially model the groundwaters and forest soil properties as independent variables in the forecast. Research of the ecophysiological reactions of pedunculate oak to changing ecological factors and competition would also be a valuable addition to such research.

\section{REFERENCES}

1. HASSELMANN K 1997 Climate-change research after Kyoto. Nature 390 (6657): 225-226. DOI: https://doi. org/10.1038/36719

2. GRUZA G, RANKOVA E, RAZUVAEV V, BULYGINA O 1999 Indicators of Climate Change for the Russian Federation. Climatic Change 42 (1): 219-242. DOI: https://doi. org/10.1023/A:1005480719118

3. TÜRKES M 1998 Influence of geopotential heights, cyclone frequency and Southern Oscillation on rainfall variations in Turkey. Int J Climatol 18 (6): 649-680. DOI: https://doi. org/10.1002/(SICI)1097-0088(199805)18:6<649::AIDJOC269>3.0.CO;2-3

4. MASON S J 1996 Climatic change over the Lowveld of South Africa. Climatic Change 32 (1): 35-54. DOI: https://doi. org/10.1007/BF00141277

5. ZHAI P, SUN A, REN F, LIU X, GAO B, ZHANG Q 1999 Changes of Climate Extremes in China. In: Karl T, Nicholls N, Ghazi A (eds) Weather and Climate Extremes. Springer, Netherlands, pp 203-218. DOI: https://doi.org/10.1007/978-94-015-92659 13

6. HEINO R, BRÁZDIL R, FØRLAND E, TUOMENVIRTA $H$, ALEXANDERSSON H, BENISTON M 1999 Progress in the Study of Climatic Extremes in Northern and Central Europe. In: Karl T, Nicholls N, Ghazi A (eds) Weather and Climate Extremes. Springer, Netherlands, pp 151-181. DOI: https:// doi.org/10.1007/978-94-015-9265-9 11

7. BOOTSMA A 1994 Long term (100 yr) climatic trends for agriculture at selected locations in Canada. Climatic Change 26 (1): 65-88. DOI: https://doi.org/10.1007/BF01094009

8. SELETKOVIĆ Z, IVKOV M, TIKVIĆ I 2003 A contribution to the research of climate element and events in Zagreb region during this century. Glas Sum Pok (special issue) 4: 25-34
9. DHMZ 2009 Fifth Croatian National Communication to the United Nations Framework Convention on Climate Change (UNFCCC) - Selected chapters: Observed climate changes in Croatia Climate Change Scenario and Impact of climate variations and changes on plants and in the risk of forest fires. Meteorological and Hydrological Service, Zagreb, Croatia, 47 p. URL: http://klima.hr/razno/publikacije/ klimatske promiene.pdf (15 September 2016)

10. PRPIĆ B 1996 Degradation of penduculate oak forests. In: Klepac D (ed) Pedunculate Oak in Croatia. Croatian Academy of Sciences and Arts, Croatian Forests Ltd., Zagreb, Croatia, pp 273-298

11. MISSON L, RASSE DP, VINCKE C, AUBINET M, FRANÇOIS L 2002 Predicting transpiration from forest stands in Belgium for the 21st century. Agric For Meteorol 111 (4): 265-282. DOI: https://doi.org/10.1016/S0168-1923(02)00039-4

12. RAUS $\oplus 1996$ Forest associations and synecological conditions of pedunculate oak. In: Klepac D (ed) Pedunculate Oak in Croatia. Croatian Academy of Sciences and Arts, Croatian Forests Ltd., Zagreb, Croatia, pp 27-54

13. KLEPAC D, FABIJANIĆ G 1996 Management of pedunculate oak forests. In: Klepac D (ed) Pedunculate Oak in Croatia. Croatian Academy of Sciences and Arts, Croatian Forests Ltd., Zagreb, Croatia, pp 264-268

14. CROATIAN FORESTS LTD Zagreb, Croatia. URL: http://portal. hrsume.hr/index.php/en/forests/general/forests-in-croatia (17 September 2016)

15. MAYER B 1996 Soils of pedunculate oak forests in Croatia. In: Klepac D (ed) Pedunculate Oak in Croatia. Croatian Academy of Sciences and Arts, Croatian Forests Ltd., Zagreb, Croatia, pp 62-71

16. SELETKOVIĆ Z 1996 Climate of pedunculate oak forests. In: Klepac D (ed) Pedunculate Oak in Croatia. Croatian Academy of Sciences and Arts, Croatian Forests Ltd., Zagreb, Croatia, pp 71-73 
17. GOVINDASAMY B, CALDEIRA K, DUFFY PB 2003 Geoengineering Earth's radiation balance to mitigate climate change from a quadrupling of $\mathrm{CO}_{2}$. Glob Planet Chang 37 (1-2): 157-168. DOI: https://doi.org/10.1016/S09218181(02)00195-9

18. VUKELIĆ J, MIKAC S, BARIČEVIĆ D, BAKŠIĆ D, ROSAVEC R 2008 Forest habitats and Forest Communities in Croatia-National Ecological Network. State Institute for Nature Protection, Zagreb, Croatia, $263 \mathrm{p}$

19. DEPARTMENT OF BOTANY AND BOTANICAL GARDEN Faculty of Science, University of Zagreb, Croatia. URL: http://hirc. botanic.hr/ (21 September 2016)

20. PHILLIPS SJ, ANDERSON RP, SCHAPIRE RE 2006 Maximum entropy modeling of species geographic distributions. Ecol Model 190 (3-4): 231-259. DOI: https://doi.org/10.1016/j. ecolmodel.2005.03.026

21. WORLD CLIM-GLOBAL CLIMATE DATA. URL: http://www. worldclim.org./ (20 September 2016)

22. FLANTUA SGA, VAN BOXEL JH, HOOGHIEMSTRA H, VAN SMAALEN J 2007 Application of GIS and logistic regression to fossil pollen data in modelling present and past spatial distribution of the Colombian savanna. Clim Dynam 29 (7): 697-712. DOI: https://doi.org/10.1007/s00382-007-0276-3

23. DICKINSON RE, ERRICO RM, GIORGI F, BATES GT 1989 A regional climate model for the western United States. Climatic Change 15 (3): 383-422. DOI: https://doi. org/10.1007/BF00240465

24. GIORGI F 1990 Simulation of Regional Climate Using a Limited Area Model Nested in a General Circulation Model. J Climate 3 (9): 941-963. DOI: https://doi.org/10.1175/15200442(1990)003<0941:SORCUA>2.0.CO;2

25. WAGGONER PE 1989 Anticipating the frequency distribution of precipitation if climate change alters its mean. Agric For Meteorol 47 (2-4): 321-337. DOI: https://doi. org/10.1016/0168-1923(89)90103-2
26. GROISMAN PY, KARL TR, EASTERLING DR, KNIGHT RW, JAMASON PF, HENNESSY KJ 1999 Changes in the Probability of Heavy Precipitation: Important Indicators of Climatic Change. Climatic Change 42 (1): 243-283. DOI: https://doi. org/10.1023/A:1005432803188

27. TIKVIĆ I, UGARKOVIĆ D, GAŠPAR J 2011 Prostorna analiza odumiranja stabala hrasta lužnjaka (Quercus robur L.) za potrebe adaptivnoga gospodarenja šumskim ekosustavima u Hrvatskoj. Croat J For Eng 32 (1): 43-54

28. MILLER J, FRANKLIN J 2002 Modeling the distribution of four vegetation alliances using generalized linear models and classification trees with spatial dependence. Ecol Model 157 (2-3): 227-247. DOI: https://doi.org/10.1016/S03043800(02)00196-5

29. LEEMANS R 1999 Applying Global Change Scenarios to assess Changes in Biodiversity. Rijksinstituut voor Volksgezondheid en Milieu (RIVM Rapport 481508012): 2-65

30. TRINAJSTIĆ । 1998 Influence of general climatic changes on the spatial disposition of climazonal forest vegetation in Croatia. In: Maceljski M (ed) Agriculture and forestry adaptibility to climate change. Croatian Academy of Sciences and Arts, Zagreb, Croatia, p 259-268

31. MATIĆ S, ORŠANIĆ M, ANIĆ I 1998 The effect of climatic changes on the structure and development of forest ecosystems. In: Maceljski M (ed) Agriculture and forestry adaptibility to climate change. Croatian Academy of Sciences and Arts, Zagreb, Croatia, pp 239-250

32. LAUBHANN D, STERBA H, REINDS GJ, DE VRIES W 2009 The impact of atmospheric deposition and climate on forest growth in European monitoring plots: An individual tree growth model. Forest Ecol Manag 258 (8): 1751-1761. DOI: https://doi.org/10.1016/i.foreco.2008.09.050

33. MATIĆ S 2000 Oak forests (Quercus sp.) in Croatia. Glas Sum Pok (special issue) 2: 67-77

34. PRPIĆ B, ANIĆ I 2000 The role of climate and hydraulic operations in the stability of the pedunculate oak (Quercus robur L.) stands in Croatia. Glas Sum Pok 37: 229-239 